\title{
ASSESSMENT OF EFFECT OF SHODHANA ON PHYTOCHEMICAL AND CHROMATOGRAPHICAL PROFILE OF DIFFERENT LEVELS OF CLASSICAL PROCESSED DANTI (BALIOSPERMUM MONTANUM WILLD.) ROOT
}

\author{
SIBA PRASAD ROUT ${ }^{1}$, V. J. SHUKLA ${ }^{2}$, RABINARAYAN ACHARYA ${ }^{3}$
}

${ }^{1}$ M.D. Scholar, Department of Dravyaguna I. P.G.T \& R.A; Gujarat Ayurved University, Jamnagar, ${ }^{2} H e a d$ of Pharmaceutical Laboratory, ${ }^{3}$ Professor and Head, Dept. of Dravyaguna, I.P.G.T \& R.A, Jamnagar

Email: drrout.sibaprasad@gmail.com

Received: 27 Dec 2016, Revised and Accepted: 20 Mar 2017

\section{ABSTRACT}

Objective: Ayurveda recommends the use of Danti root after Shodhana (Processing/Purification) where the powder Pippali (Piperlongum Linn.) fruit, honey and Kusha (Desmostachya bippinata Stapf.) leaves are being used. But the additive effect of all these drugs on Danti root are yet to be explored scientifically. Principal component analysis (PCA), a multivariate data analysis technique targeting to assess the discrimination effect of psychic nut, for evaluating the additive effect, can be used to assess the effect of Shodhana on preliminary physicochemical, phytochemical parameters upon four levels of Danti (Baliospermum montanum Willd.) root.

Methods: Roots of raw Danti, after proper botanical authentication, were subjected for classically recommended Shodhana procedure and four groups of Danti root like raw Danti (RD), Classical processed Danti root (CPDR), Kusha processed Danti root (KPDR), water processed Danti root (WPDR) were obtained at various levels of Danti Shodhana. Methanolic macerated extracts of all four Danti root groups were subjected for preliminary physicochemical, phytochemical and chromatographic screening. The obtained data were analyzed with the help of the Un-scrambler Camo Software for multivariate data analysis.

Results: The methanolic and water extractive value of CPDR group is more than remaining sections holding lower ash value and high-intensity colour reaction during phytochemical screenings of steroid, flavonoid etc.

Conclusion: Analysis of PCA technique suggests a similar trend in between RD and KPDR group while CPDR and WPDR on a different in score plot.

Keywords: Danti, Shodhana, PCA, Classical processed Danti root, Baliospermum montanum

(C) 2017 The Authors. Published by Innovare Academic Sciences Pvt Ltd. This is an open access article under the CC BY license (http://creativecommons.org/licenses/by/4.0/) DOI: http://dx.doi.org/10.22159/ijcpr.2017v9i3.18883

\section{INTRODUCTION}

Physicochemical analysis provides the objective parameters to fix up the standards for quality of raw drugs as well as finished products. Analytical study of a drug helps to interpret the pharmacokinetics and pharmacodynamics of the same [1]. Ayurveda has described numerous herbal, mineral, herbomineral drugs, including poisonous and semipoisonous drugs, in all its treaties and advocated to use poisonous plants after passing through Shodhana procedures. The concept of Shodhana (detoxification technique/processing) in Ayurveda is not only a process of purification/detoxification, but also a process to enhance the potency and efficacy of the drugs [2]. More to say a process where different qualities are depicted through which there is 'gunaantardhana' (transformation in properties) in the primary substance rendering it safe, as well as many desired qualities, are imbibed in it.[3]. Effect of Shodhana on different phytopharmacological properties of different drugs like Guggulu (Commiphora mukul Engl [4], Kupiluseeds [5], Vatsanabha [6] have been reported. Shodhana procedures have been advocated for both herbal as well as mineral drugs based on their toxic nature. Certain medicinal plants like Danti (Baliospermum montanum Willd), Vacha (Acorus calamus Linn.), Vriddhadaru (Argyreiaspeciosa Sweet.), Hingu (Ferula foetida Bioss.), Kampillaka (Mallotusphilippensis (Lamk.) Muell-Arg.) And Guggulu (Commiphora mukul (Hook. ex. Stocks) Engl.) etc. though have not been categorized under poisonous drugs, still have been recommended to pass through specific Shodhana process before administration for the medicinal purpose [7]. According to Charaka Danti root should be used after being delivered through certain Samskara (processing techniques). In the light of the above background, the present study was designed and undertaken to study of Danti root sample to assess the effect of Shoshana on preliminary physicochemical, phytochemical and chromatographical fingerprinting.

\section{MATERIALS AND METHODS}

\section{Collection and authentication}

Danti (Baliospermum montanum Willd.), basing upon its morpho-logical characters were identified from its natural habitat, Bolangir forest area of Odisha and authenticated by comparing with the reported characters mentioned in the Flora of Orissa with the help of local taxonomist [8] and the roots were collected in the month of February 2016. The herbarium was preserved in pharmacognosy laboratory of IPGT and RA with voucher specimen (No. PHM/6208/15-16) for future reference.

\section{Sample preparation}

Collected raw Danti(R. D) root being washed properly was smeared with a thin layer of paste prepared from a powder of Pippali (Piper longum Linn.) and honey then wrapped with leaves of Kusha (Desmostachya bipinnata Stapf.). The resultant was coated with mud and fomented with steam at temperature $125^{\circ} \mathrm{C}$ for $3 \mathrm{~h}$ [9]. This process was adopted for three times obtaining 3 batches of Classical processed Danti root (CPDR). Then the obtained three batches of roots were dried in sun rays, then grinded with a mechanical grinder, assembled, finally, the coarse powders were separated by sieving using 80 meshes and stored in an airtight container for further use. Individual powders at different levels of Danti Shodhana like Kusha processed Danti root (KPDR) group and Water processed Danti root (WPDR) group was also obtained in the same way.

\section{Preparation of extract}

Different groups of Danti root were grinded into coarse powders and then subjected to macerated with methanol (Merck, Germany) in a ratio of 1:5. The extracts were filtered and the solvents were evaporated under temperature controlled water bath. The dried extracts were stored in a refrigerator at $4{ }^{\circ} \mathrm{C}$ until further analysis [10].

Physicochemical and phytochemical study

The loss on drying, moisture, ash, extractive value and other physicho-chemical constant were determined by using the association of Official Analytical Chemist [11]. Preliminary phytochemical investigations such as Molisch's test, Salkowski test, 
Keller-Killiani test, Flavonoid test, Dragendorff's test and test for tannins were performed according to Harbone following standard protocol [12].

\section{Quantitative UV-VIS analysis}

\section{HPTLC study}

Chromatography is a powerful analytical method suitable for the separation and quantitative determination of a considerable number of compounds even from complicated matrix [13-15]. HPTLC study was carried out with methanolic extract. Each of $5 \mu$ methanol extract of RD, CPDR, KPDR, and WPDR were spotted on pre-coated Silica Gel GF254 plates by means of Camag Linomat V sample applicator. The mobile phase consisted of Toluene: Chloroform: Acetone 4:2.5:3.5 V/V. After development, the densitometry scan was performed with a Camag T. L. C. scanner III in reflectance absorbance mode at $254 \mathrm{~nm}$ and $366 \mathrm{~nm}$ under the control of Wincats software. Further spectral comparison was also performed.

\section{Documentation}

With the TLC Visualizer under short UV $254 \mathrm{~nm}$ and long UV 366.

\section{Total flavonoid content}

Total flavonoid content (TFC) was determined using aluminium chloride method as reported by Cook NC, Samman S. [16]. About 2 $\mathrm{ml}$ of methanolic extract of KPDR, RD, CPDR, WPDR $(\mathrm{mg} / \mathrm{ml})$ was dispensed into a test tube, followed by $1.5 \mathrm{ml}$ of methanol, $0.1 \mathrm{ml}$ of aluminium chloride (10\%), $0.1 \mathrm{ml}$ of $1 \mathrm{M}$ potassium acetate and 2.8 $\mathrm{ml}$ of distilled water. The reaction mixture was mixed, allowed to stand at room temperature for $30 \mathrm{~min}$ before absorbance was read at $514 \mathrm{~nm}$. TFC was expressed as chyrisin (5, 7-dihydroxy flavone) equivalent (QE) in $\mu \mathrm{g} / \mathrm{ml}$ material.

\section{Principal component analysis (PCA)}

Principal component analysis (PCA) is a technique used to emphasise variation and bring out strong patterns in a dataset. It's often used to make data easy to explore and visualize. Principal component analysis provides a method for understanding the meaning of a data set by extracting a smaller series of important components that account for the variability in the data. Principal component analysis is a variable reduction procedure. It is useful when you have obtained data on a number of variables (possibly a large number of variables) [17-18].

\section{Data analysis}

All the physicochemical data were tabulated in two-way matrix form. One way is a respective sample and another way thermal and solubility category parameter (LOD, AV and AIA, WSE and MSE). The single table data were executed for PCA with help of Unscrambler Camo $®$ student version.

\section{RESULTS AND DISCUSSION}

\section{Physico-chemical analysis}

The result of the physicochemical properties of the four Danti samples are presented in table 1.

Table 1: Physico-chemical parameters of root powder of KPDR, CPDR, RD, and WPDR powder (Result expressed as \% w/w, $n=3$, mean \pm SD)

\begin{tabular}{|c|c|c|c|c|c|}
\hline S. No. & Test & CPDR & KPDR & WPDR & RD \\
\hline 1 & Loss on drying at $110^{\circ} \mathrm{C}$ & $14.5 \pm 1.6 \%$ & $9 \pm 0.12 \%$ & $12.6 \pm 0.23 \%$ & $9.1 \pm 0.26 \%$ \\
\hline 2 & Ash value (w/w) & $7.5 \pm 0.42 \%$ & $8.1 \pm 0.38 \%$ & $8.6 \pm 0.29 \%$ & $9.4 \pm 0.26 \%$ \\
\hline 3 & Acid Insoluble ash & $1.8 \pm 0.4 \%$ & $2.1 \pm 0.3 \%$ & $1.9 \pm 0.5 \%$ & $2.2 \pm 0.4 \%$ \\
\hline 4 & Water soluble extract & $7.6 \pm 0.71 \%$ & $4.3 \pm 0.52 \%$ & $4.6 \pm 0.35 \%$ & $4.1 \pm 0.32 \%$ \\
\hline 5 & Methanol soluble extract & $9.52 \pm 0.47 \%$ & $2.32 \pm 0.63 \%$ & $3.5 \pm 0.81 \%$ & $3.36 \pm 0.70 \%$ \\
\hline 6 & p. $\mathrm{H}$ & $7.0 \pm 0.42$ & $6.5 \pm 0.44$ & $6.5 \pm 0.46$ & $6.5 \pm 0.39$ \\
\hline 7 & No of Spots@254 nm & 09 & 10 & 09 & 10 \\
\hline 8 & No of Spots@366nm & 06 & 07 & 06 & 07 \\
\hline
\end{tabular}

Loss on drying signifies the considerable amount of moisture in order to control definite strength and prevent decompositionLoss on drying in CPDR is $5.4 \%$ and that in WPDR is $3.5 \%$ as compared to RD which suggests that CPDR group was adhered to madhu which is a great source of oleoresin content and KPDR group was exposed to water directly, so due to absorption of direct absorption of water during fomentation, there is evidence of increase in LOD. In rest groups, the value of loss on drying is in identical range. Ash values were used to detect the presence of siliceous contamination and water soluble salts in favor of determining authenticity and purity of drugs,As regards to Ash value, there is evidence of a decrease of ash value in CPDR i. e 1.9\%, that of KPDR is $1.28 \%$ and in WPDR is $0.8 \%$ as compared to R. D. This may be due to the fact that CPDR after being obtained through shodhana, there occurs addition of various organic materials like Pippali(a good source of volatile materials), honey, fragments of Kusha which may have been transformed to different level chemical moieties signaling in variation of reduced ash value and increased LOD in CPDR group. The water and alcohol soluble extractive value shows no significant changes indicating the percentage of soluble polar and moderatly polar component like sugar,glycosides etc. remains same in all groups.

\section{Phytochemical analysis}

The phytochemical screening results suggest that the methanol soluble extractives indicate the presence of carbohydrate, flavonoids, polyphenol, steroids,glycoside, phenolic and tannin content which have been presented in table 2 .

Table 2: Preliminary Phytochemical analysis of Coarse Powder of KPDR, CPDR, RD, and WPDR

\begin{tabular}{|c|c|c|c|c|c|}
\hline Phytochemical & Test & R. D & WPDR & KPDR & CPDR \\
\hline Steroid & Salkowski reaction & + & + & + & + \\
\hline Phenolic and Tannin & Lead acetate solution & + & + & + & + \\
\hline Flavonoids & Shinoda Test & + & + & + & + \\
\hline Protein & Biuret Test & - & - & - & - \\
\hline Alkaloid & Dragendroff"s test & - & - & - & - \\
\hline Glycoside & Keller-Killiani test & + & + & + & + \\
\hline Sapponin & Foam Test & - & - & - & - \\
\hline Amino Acid & Ninhydrine test & - & - & - & - \\
\hline Carbohydrate & Molish's Test & + & + & + & + \\
\hline
\end{tabular}

+= present,-= absent, R. D-Raw Danti, WPDR-Water processed Danti root, KPDR-Kusha processed Danti root, CPDR-Classical processed Danti root. 


\section{Total flavonoid content}

Total flavonoid content of the extract was estimated previously explained assay method. The standard calibration curve of chrysin

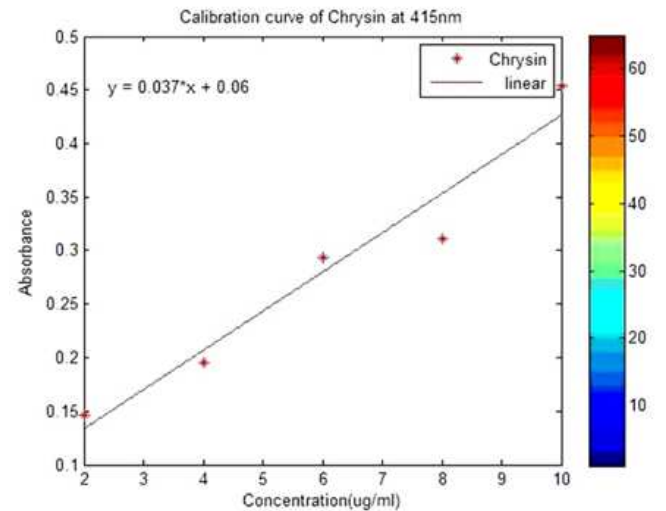

was established. The standard chrysin indicated 0.146, 0.195, $0.294,0.311,0.454$ absorbance at $2,4,6,8,10(\mu \mathrm{g} / \mathrm{ml})$ respectively (fig. 1). Total flavonoid content of that formulation is described in table 3 .

Fig. 1: Linear standard curve of chrysin (dihydroxy flavones) and it's residual

Table 3: The content of total flavonoid in four respective samples

\begin{tabular}{llll}
\hline Samples & KPDR & RD & CPDR \\
\hline Total flavonoid chrysin equivalent $(\mu \mathrm{g} / \mathrm{ml})$ & $5.81 \pm 0.02$ & $30.02 \pm 0.04$ & $5.21 \pm 0.05$ \\
\hline
\end{tabular}

Data were presented as mean \pm SD $(n=3)$ and also $95 \%$ confidential limit. Standard curve for total, Flavonoids: $y=0.037 \mathrm{x}+0.06, \mathrm{r}^{2}=0.94$.

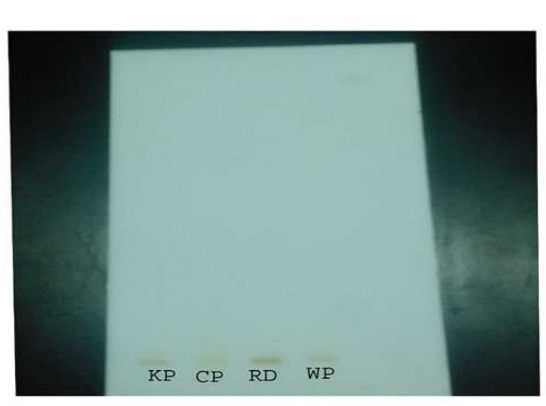

A
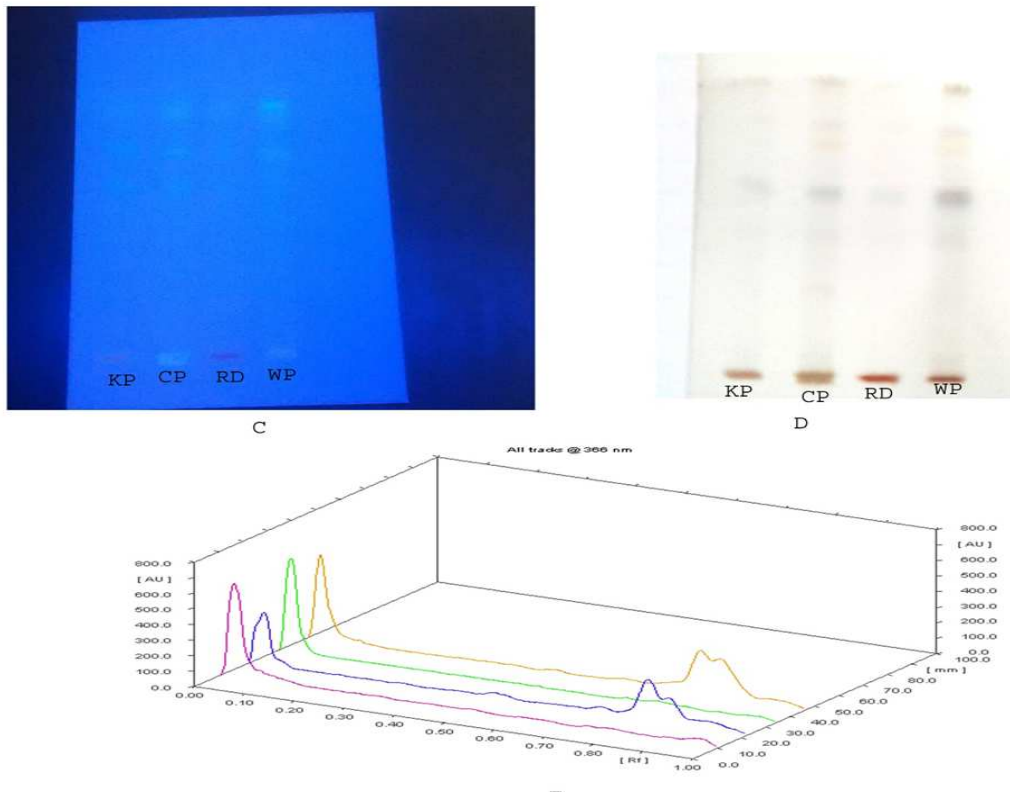

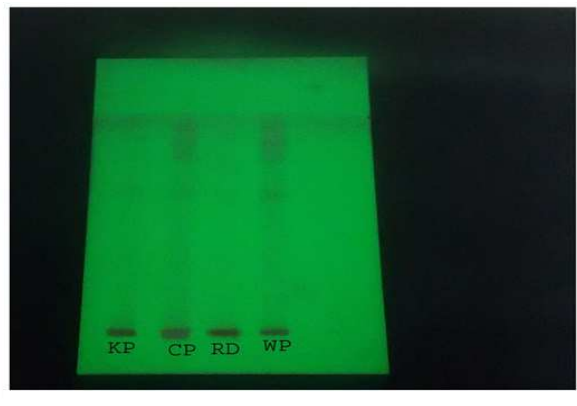

B

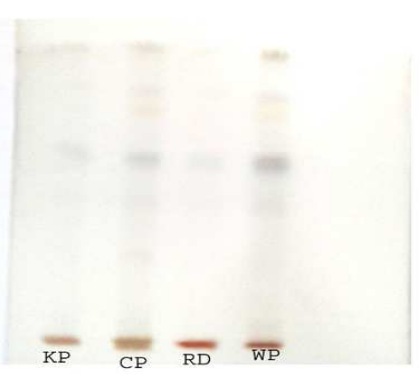

Fig. 2: Separation of methanol extract on HPTLC Si $60 \mathrm{~F}_{254}$ with Toluene: Chloroform: Acetone (4:2.5:3.5 V/V), chamber saturation, stained with the vanillin-sulfuric acid reagent. Tracks: 1 . KPDR extract, 2 . CPDR extract, 3. RD extract, 4. WPDR extract. A-Day light, B-Short UV $(254 \mathrm{~nm})$, C-Long UV (366 $\mathrm{nm})$, D-After Visualizing agent. E-3D graph of the respective samples 
Flavonoids are the class of secondary metabolites remains present in a plant in the form of a polyphenolic molecule or in the form of glycoside linkage which is a polar soluble chemical entity as well as aqueous soluble. On keen observation, total flavonoid chrysin equivalent $(\mu \mathrm{g} / \mathrm{ml})$ concentration among all four groups of Danti reveals that KPDR and RD has been evaluated approximately in similar range while a significant marked difference in the value of total flavonoid chrysin equivalent $(\mu \mathrm{g} / \mathrm{ml})$ concentration was found in between RD (i.e.30.02 \pm 0.04 ) and CPDR (10.18 \pm 0.06$)$ group. It can be assumed that RD group after being exposed to shodhana, some of the chemical moiety of RD have been absorbed in water resulting in decreased total flavonoid chrysin equivalent $(\mu \mathrm{g} / \mathrm{ml})$ concentration value in CPDR.

\section{High-performance thin layer chromatographic profiling:}

In this study, combination of toluene, chloroform and acetone (8:5:7 $\mathrm{v} / \mathrm{v} / \mathrm{v}$ ) as mobile phase of HPTLC analysis of four respective samples resulted in well-separated, compact and symmetrical

Bands. HPTLC fingerprint profiles of the above explaining samples methanolic extracts are shown in (fig. 6-A-D). HPTLC fingerprinting profiles respective Rf values have been depicted in table 4 and 5 . In table 4 , the fingerprint patterns of alcoholic extract of the KPDR, CPDR, RD, WPDR at $254 \mathrm{~nm}$ are shown nine, ten, nine and ten peaks. On the other hand in table-5, at $366 \mathrm{~nm}$ respected samples six, seven, six and seven peaks are found in favor of target class of Moeity polyphenol and flavonoid.

Table 4: Showing HPTLC profile for Coarse Powder of KPDR, CPDR, RD, and WPDR at 254 nm (Short UV)

\begin{tabular}{|c|c|c|c|c|c|}
\hline \multirow{3}{*}{$\begin{array}{l}\text { Solvent system } \\
\text { Toluene: } \\
\text { Chloroform: } \\
\text { Acetone }\end{array}$} & \multirow{3}{*}{$\begin{array}{l}\text { Track } \\
\text { No }\end{array}$} & \multicolumn{4}{|c|}{ Under UV light } \\
\hline & & \multicolumn{4}{|c|}{$254 \mathrm{~nm}$ (Short UV) } \\
\hline & & $\begin{array}{l}\text { Number of } \\
\text { spots }\end{array}$ & Max Rf. Value & Max Height & Area in \% \\
\hline $4: 2.5: 3.5 \mathrm{~V} / \mathrm{V}$ & $\begin{array}{l}\text { Track } 1 \\
\text { (KPDR) }\end{array}$ & 09 & $\begin{array}{l}0.02,0.14,0.34,0.38,0.49 \\
0.64,0.73,0.89,0.96\end{array}$ & $\begin{array}{l}\text { 693.1, 13.1, 31.4, 24.0, 14.6, } \\
72.1,12.8,44.9,186.5\end{array}$ & $\begin{array}{l}\text { 63.27, 1.00, 3.60, 1.71, 1.71, } \\
7.77,0.92,3.06,16.95\end{array}$ \\
\hline & $\begin{array}{l}\text { Track } 2 \\
\text { (CPDR) }\end{array}$ & 10 & $\begin{array}{l}0.03,0.32,0.37,0.43,0.49 \\
0.62,0.70,0.80,0.88,0.93\end{array}$ & $\begin{array}{l}334.9,64.4,32.9,17.3,34.0 \\
92.4,20.5,140.9,87.9,133.7\end{array}$ & $\begin{array}{l}23.45,8.22,3.17,1.57,6.44 \\
12.44,1.66,13.00,13.50,16.57\end{array}$ \\
\hline & $\begin{array}{l}\text { Track } 3 \\
\text { (RD) }\end{array}$ & 09 & $\begin{array}{l}0.02,0.32,0.37,0.52,0.62 \\
0.70,0.76,0.87,0.95\end{array}$ & $\begin{array}{l}\text { 569.6, 31.1, 19.7, 14.2, 43.3, } \\
16.5,33.0,51.1,110.4\end{array}$ & $\begin{array}{l}55.89,4.18,2.81,1.41,6.27 \\
0.85,6.58,5.85,16.15\end{array}$ \\
\hline & $\begin{array}{l}\text { Track } 4 \\
\text { (WPDR) }\end{array}$ & 10 & $\begin{array}{l}0.02,0.10,0.32,0.37,0.48 \\
0.62,0.70,0.79,0.84,0.96\end{array}$ & $\begin{array}{l}\text { 601.5, 12.2, 17.5, 23.2, } 26.4 \\
151.7,23.6,151.1,208.0,195.8\end{array}$ & $\begin{array}{l}32.56,0.18,1.09,1.43,2.56 \\
12.71,1.08,10.19,20.25,17.95\end{array}$ \\
\hline
\end{tabular}

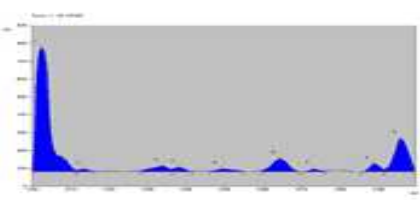

A
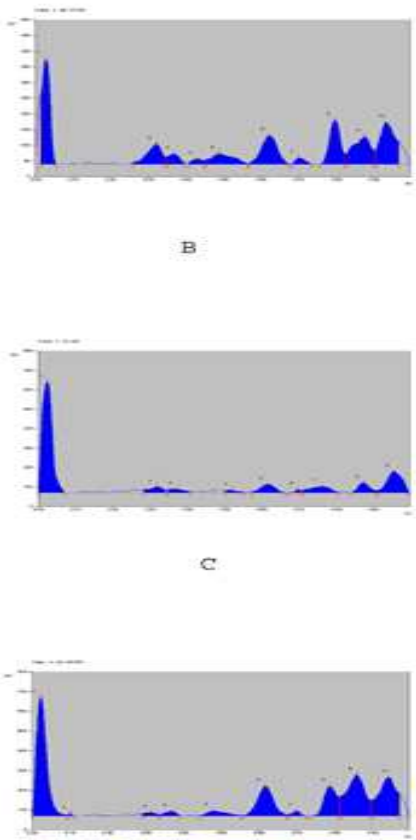
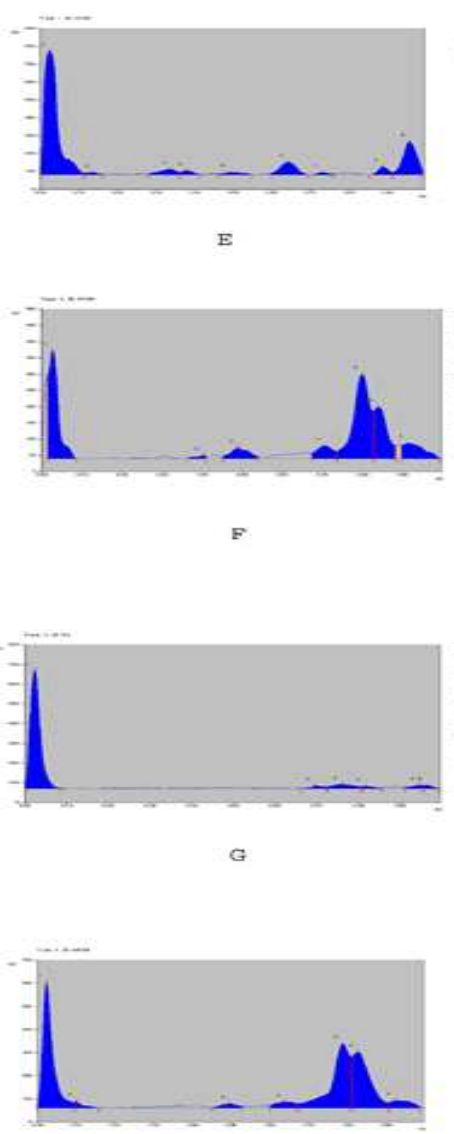
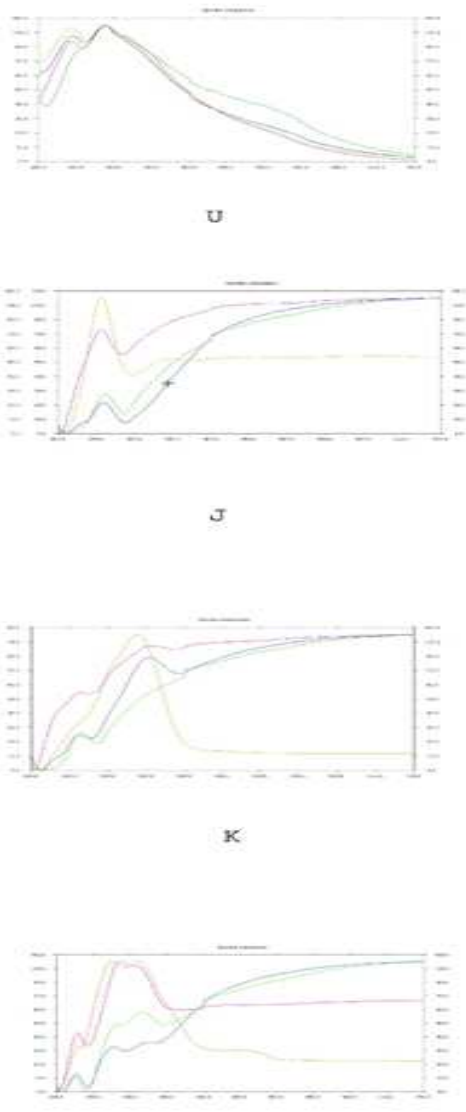

Fig. 3: HPTLC densitometry chromatogram (at $254 \mathrm{~nm}$ ) of methanolic extracts of A-KPDR, B-CPDR, C-RD, D-WPDR andHPTLC densitometry chromatogram (at $366 \mathrm{~nm}$ ) of methanolic extracts of E-KPDR,F-CPDR, G-RD, H-WPDR and spectral comparison of the respective $\mathrm{Rf}$ as $\mathrm{U}, \mathrm{J}, \mathrm{K}$ and $\mathrm{L}$ with Toluene: Chloroform: Acetone 4:2.5:3.5 V/V as the mobile phase

The densitogram of respective samples are visualized at $254 \mathrm{~nm}$ (fig. 3, A-D) and at $366 \mathrm{~nm}$ (fig. 3, E-H) along with four samples spectral comparison of various Rf (fig 3, U-L). 
Table 5: Showing HPTLC profile for coarse powder of KPDR, CPDR, RD, and WPDR at $366 \mathrm{~nm}$ (Short UV)

\begin{tabular}{|c|c|c|c|c|c|}
\hline Solvent system & \multirow[t]{3}{*}{ Track No } & \multicolumn{4}{|l|}{ Under UV light } \\
\hline Toluene: Chloroform: Acetone & & $366 \mathrm{~nm}$ (Short UV) & & & \\
\hline $4: 2.5: 3.5 \mathrm{~V} / \mathrm{V}$ & & Number of spots & Max Rf. Value & Max Height & Area in \% \\
\hline & Track 1 & 06 & $0.03,0.50,0.74$ & $602.9,13.1,14.6$ & $83.90,1.72,1.45$ \\
\hline & (KPDR) & & $0.78,0.90,0.96$ & $19.9,17.2,36.3$ & $3.93,2.02,6.99$ \\
\hline & Track 2 & 07 & $0.03,0.40,0.49$ & 334.0,11.1,33.3, & $27.63,0.82,5.09$ \\
\hline & (CPDR) & & $0.71,0.80,0.84,0.91$ & $39.8,259.6,160.0$ & $5.48,35.15,17.15,8.68$ \\
\hline & Track 3 & 06 & $0.02,0.70,0.76$ & $47.6,602.0,17.1$ & $83.98,2.55,6.65$ \\
\hline & $(\mathrm{RD})$ & & $0.82,0.95,0.97$ & $23.2,17.2,17.3$ & $1.98,2.68,2.17$ \\
\hline & Track 4 & 07 & $0.02,0.10,0.50$ & $543.0,30.6,19.0$ & $33.58,1.33,1.88$ \\
\hline & (WPDR) & & $0.64,0.79,0.83,0.92$ & $27.3,279.2,242.6,32.8$ & $3.22,30.19,25.48,4.27$ \\
\hline
\end{tabular}

Chromatographic performance of CPDR, KPDR, WPDR and RD on silica gel at $254 \mathrm{~nm}$ using mobile phase toluene, chloroform and acetone $(8: 5: 7 \mathrm{v} / \mathrm{v} / \mathrm{v})$ shows that the compound fraction separated at Rf 0.03 found to be similar as UV-Vis spectrum shows similarity while component separated at $0.32,0.79$ and 0.87 shows similarity between KPDR and WPDR chromatographic curve while RD and CPDR chromatographic curve remains to each other distinct respectively. It suggests that in CPDR, the process of steaming with vapour in water as well with the help of pippali and honey modulates some of the components to produce a new chemical entity that has produced a distinct chromatographic graph to RD.

\section{Multivariate analysis}

PCA was executed to provide a data structure study in a reduced dimension, covering the maximum amount of information present in the data. It is value revealing that PCA is among the most versatile of all chemometric methods as it involves a mathematical procedure that reduces data dimensionality. The data matrix corresponding to the physicochemical parameters along with chromatographic data (table 1) was submitted to PCA in order to show possible trends in their values and emphasize the similarities and differences between various samples on a score plot.
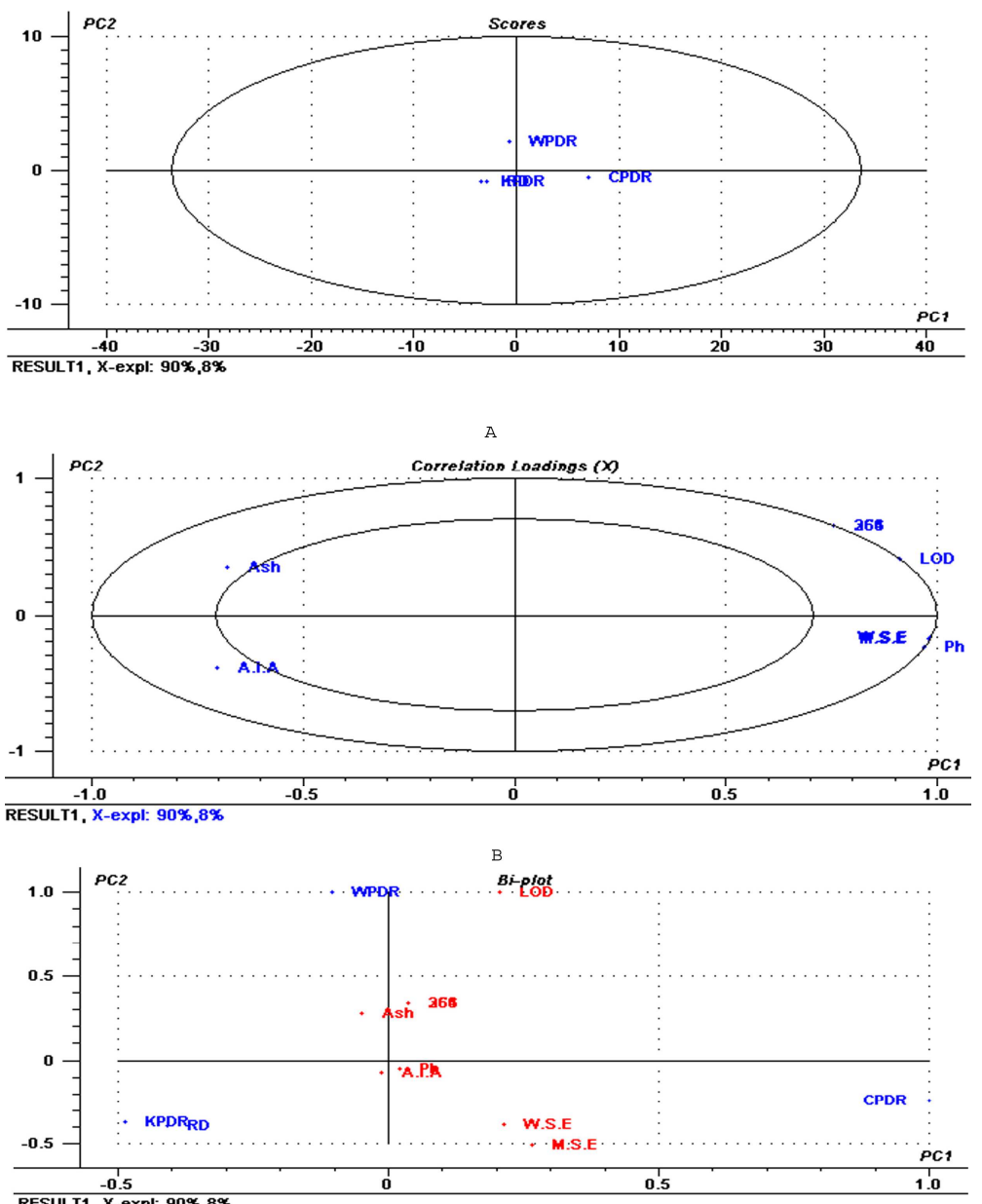

RESULT1, X-expl: 90\%,8\%

Fig. 4: (A) PCA score plot and (B) loading plot (C) Bi-plot of three samples based on its physicho-chemical and chromatographic separation behavior showing the distribution pattern of samples and various physicochemical parameters contributing to the groups respectively. The ellipse represents the Hotelling T2 with $95 \%$ confidence in score plot

The score plot in fig. 4-A showed that the Danti samples (KPDR-RD) were grouped together in the upper left quadrant of the score plot, though one samples RD appear below the horizontal line of the score plot. CPDR samples were well separated from the other samples 
scattered in the lower right quadrant, except for the sample WPDR which appeared in the upper right quadrant From the loading plot in fig. 4-B, it appeared that the ASH, LOD, and p. H, ASE, 254 and 366 sensitive separated peaks were the physicochemical, chromategraphical parameters contributing to the grouping of Danti samples, and that these attributes corresponded to the PC1 which explained about $98 \%$ of the total variance. It should be noted that CPDR samples are differentiated from other samples by their higher water, alcohol extractive value and chromatographic pattern as well as lower ASH value content.

\section{CONCLUSION}

Comparisons of different physicochemical parameteric observations like loss on drying, water soluble extract, methanolic soluble extractive value, $\mathrm{pH}$, chromatographic fingerprinting at $254 \mathrm{~nm}$ and $366 \mathrm{~nm}$ between different samples of Danti obtained from various level of Danti shodhana (purificatory conditions) shows the level of discriminations in between water processed Danti root, classical processed Danti root, kusha processed Danti root, raw Danti root groups. With respect to physicochemical variables among all groups of Danti, classical processed Danti root remains at upper hand among them. Discrimination upon one target group like total flavonoid chrysin equivalent $(\mu \mathrm{g} / \mathrm{ml})$ concentration between raw Danti root and classical processed Danti root has justified that shodhana (purification) has produced an impact upon the between raw Danti root and classical processed Danti root. Based on physicochemical data, it is observed that pattern recognition techniques such as PCA have shown potent discrimination at various levels of Danti samples. Analysis of all these datas shows water soluble extractive value is the most prominent value that has been disturbed to a significant level in classical processed Danti root as compared to raw Danti. The overall decrease in Ash value, increase in loss on drying, decrease in total flavonoid chrysin equivalent $(\mu \mathrm{g} / \mathrm{ml})$ concentration and other chromatographic findings of classical processed Danti root clearly discriminates it from raw Danti. Hence on the basis of these findings, it can be concluded that shodhana (Purification) has a definite imact upon Danti and the observed parameter may act as a referencing tool for further scientific advancement.

\section{ACKNOWLEDGEMENT}

The authors thank to the Director, IPGT \& RA Jamnagar, for providing financial support. The author is exclusively thankfull to Jayanta Kumar Maji and all the associate staffs of pharmaceutical lab, the Gujarat Ayurveda University for the support.

\section{CONFLICT OF INTERESTS}

The authors declare no conflicts of interest.

\section{REFERENCES}

1. Maurya SK, Seth A, Laloo D, Singh NK, Gautam DN, Singh AK. Śodhana: an ayurvedic process for detoxification and modification of therapeutic activities of poisonous medicinal plants. Ancient Sci Life 2015;34:188.

2. Charaka Samhita, Ayurveda-Deepika. Commentary of Chakrapanidatta by Kashinatha Shastry and Gorakhanatha Chaturvedi (Ed.), Chaukhamba Surbharati Prakashan, Varanasi, Vimanasthana 01/22; 2007. p. 680.

3. Acharya R. Shodhana: an ayurvedicde toxification technique and its impact on certain medicinal plants. J Ayurveda 2011;5:69-76.
4. Rachana Kamble, Sadhana Sathaye, Shah DP. Evaluation of the antispasmodic activity of different Shodhit guggulu using different shodhan process. Int J Pharm Sci 2008;70:368-72.

5. Mitra S, Shukla VJ, Acharya R. Effect of shodhana (processing) on Kupeelu (Strychnos nux-vomica Linn.) with special reference to strychnine and brucine content. Int Quarterly J Res Ayurveda 2011:1;32:402.

6. Deore SL, Moon KV, Khadabadi SS, Deokate UA, Baviskar BA. Evaluation of toxicity of 'Vatsanabha' (Aconitum ferox, Ranunculaceae) before and After Shodhana. J Young Pharm 2013;5:3-6.

7. Santosh Kumar Maurya, Ankit Seth, Damiki Laloo, Narendra Kumar Singh, Śodhana. An ayurvedic process for detoxification and modification of therapeutic activities of poisonous medicinal plants. Anc Sci Life 2015;34:188-97.

8. Saxena HO, Brahmam M. The Flora of Orissa. Vol. II. Regional Research Laboratory, Orissa Forest Development Corporation Ltd. Bhubaneswar; 1990. p. 897.

9. Charaka Samhita, Ayurveda-Deepika. Commentary of chakrapanidatta by kashinatha shastry and gorakhanatha chaturvedi. Ed. Chaukhamba Surbharati Prakashan, Varanasi, Kalpasthana12/05; 2007. p. 936.

10. The Ayurvedic Pharmacopeia of India. edition $1^{\text {st }}$ Govt. of India. Ministry of Health and Family welfare, Department of I. S. M. and H., New Delhi, Part-I, Volume-I; 2004. p. 143.

11. Official Methods of Analysis. 15th Edn. Association of Official Analytical Chemists. Washington DC. USA; 1990.

12. Harbourne JB. Phytochemical methods: a guide to modern techniques of plant analysis. Ghapman and hall, London; 1998. p. 4-120.

13. Kasture AV, Wadodkar SG, Mahadik KR, More HN. Pharmaceutical analysis, Industrial Methods. Vol. II, Nirali Prakashan; 2008.

14. William H. Edi. Official methods of analysis, Association of Official Agricultural chemists Washington. 4th Ed; 1960.

15. Baxi AJ, Shukla VJ, Bhatt UB. Methods of qualitative testing of some Ayurvedic formulations. Jamnagar: Gujarat Ayurved University 2001;5:512.

16. Cook NC, Samman S. Flavonoids-chemistry, metabolism, cardioprotective effects, and dietary sources. J Nutr Biochem 1996; 7:66-76.

17. Gemperline P. Editor. Practical Guide to Chemometrics. 2nd edition. Chapter 4. CRS Press. Taylor and Francis group; 2006. p. 342.

18. Glenn J Myatt, Wayne P Johnson. Making sense of data II-A practical guide to data visualization, advanced data mining methods, and applications, John Wiley and Sons, Inc., Hoboken, New Jersey; 2009. p. 126-7.

19. Anonymous. The Ayurvedic Pharmacopoeia of India. Vol. 03. 1st Ed. New Delhi: Govt. of India, Ministry of Health and Family Welfare; 1999. p. 41-2.

\section{How to cite this article}

- Siba Prasad Rout, VJ Shukla, Rabinarayan Acharya. The phytochemical and chromatographical effect upon different levels of classical recommended danti (Baliospermum montanum willd.) root shodhana. Int J Curr Pharm Res 2017;9(3):31-36. 